\title{
Increased understanding leads to increased complexity: Molecular mechanisms of pulmonary arterial hypertension
}

\author{
Victor A. Ferraris, MD, $\mathrm{PhD}$ \\ From the Department of Surgery, University of Kentucky, Lexington, Ky. \\ Disclosures: Author has nothing to disclose with regard to commercial support. \\ Received for publication June 6, 2016; accepted for publication June 9, 2016; available ahead of print July 7, 2016. \\ Address for reprints: Victor A. Ferraris, MD, PhD, University of Kentucky, A301 Kentucky Clinic, 740 S Lime- \\ stone, Lexington, KY 40536-0284 (E-mail: Ferraris@earthlink.net). \\ J Thorac Cardiovasc Surg 2016;152:1188-90 \\ $0022-5223 / \$ 36.00$ \\ Copyright (c) 2016 by The American Association for Thoracic Surgery \\ http://dx.doi.org/10.1016/j.jtcvs.2016.06.003
}

Salusin- $\beta$ is a bioactive peptide that was discovered by means of computer-assisted search of full-length, enriched, human complementary DNA libraries. ${ }^{1}$ This search found a previously unidentified 20-amino acid peptide translated from messenger RNA of the TOR $2 A$ gene group. Expression of the TOR $2 A$ messenger RNA is ubiquitous, and reactive salusin- $\beta$ can be detected in many human specimens, including plasma and urine. In the original description of the actions of salusin- $\beta$, intravenous administration of salusin- $\beta$ in rats was reported to cause rapid and profound hypotension and bradycardia. Salusins increase intracellular calcium, upregulate a variety of genes, and induce cell mitogenesis. ${ }^{1}$ Subsequently, salusin- $\beta$ was found to accelerate inflammatory responses in vascular endothelium by stimulating the transcription factor nuclear factor $\kappa$ light-chain enhancer of activated B cells $(\mathrm{NF}-\kappa \mathrm{B}){ }^{2}$

The manuscript by $\mathrm{Xu}$ and coauthors ${ }^{3}$ in this issue of The Journal of Thoracic and Cardiovascular Surgery is a busy discussion of the effects of salusin- $\beta$ on a rat model of pulmonary arterial hypertension (PAH) induced by monocrotaline. Salusin- $\beta$ is notoriously difficult to measure in living tissues. $\mathrm{Xu}$ and coauthors ${ }^{3}$ performed a robust series of experiments aimed at defining the impact of salusin- $\beta$ on inflammation-related PAH. They used standard methods to define the effect of salusin- $\beta$ on the development of PAH. Their experiments are well constructed and seemingly do not contain any significant flaws. Through a combination of in vitro and in vivo experiments, they describe at least 5 separate studies relating to salusin- $\beta$ and PAH as follows:

1. Identify salusin- $\beta$ expression in macrophages and vascular endothelial cells in the lungs of monocrotalinetreated rats.

2. Use polyclonal antibodies to block the in vivo effects of salusin- $\beta$ in their rat model.

3. Measure the direct hemodynamic effects of salusin- $\beta$ in monocrotaline-treated rats.

4. Assess the effect of salusin- $\beta$ on the transcription factor $\mathrm{NF}-\kappa \mathrm{B}$, in monocrotaline-treated rats with $\mathrm{PAH}$.

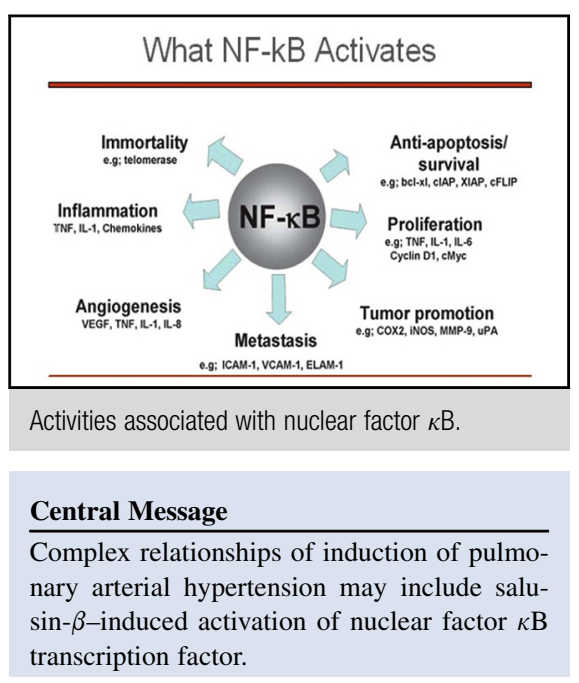

See Article page 1177.

5. Salusin- $\beta$ stimulated endothelial cell adhesion, accelerated tube formation, and upregulated cytokine expression in cultured human PAH cells in vitro.

Their appropriate conclusions from these experiments are that salusin- $\beta$ is likely a contributor to the inflammatory changes associated with development of $\mathrm{PAH}$, primarily through activation of NF- $\kappa \mathrm{B}$.

$\mathrm{NF}-\kappa \mathrm{B}$ is a protein complex found in the cytoplasm that can migrate to the nucleus to activate gene transcription. NF- $\kappa \mathrm{B}$ is found in almost all animal cell types and controls transcription of DNA, cytokine production, and cell survival. It is involved in cellular responses to multiple stimuli, including stress, cytokine stimulation, free radicals, and bacterial or viral antigens (https://en.wikipedia.org/wiki/NF-\% $\%$ E \% $\mathrm{BAB})$. Incorrect regulation of $\mathrm{NF}-\kappa \mathrm{B}$ has been linked to cancer, inflammatory and autoimmune diseases, septic shock, viral infection, and improper immune development.

$\mathrm{NF}-\kappa \mathrm{B}$ consists of either heterodimers or homodimers formed by the members of the NF- $\kappa \mathrm{B}$ family (Figure 1). In mammalian cells, there are $5 \mathrm{NF}-\kappa \mathrm{B}$ family members that have various functions, including forming dimers that bind to nuclear DNA (RelA and p50 in Figure 1). Some forms of $\mathrm{NF}-\kappa \mathrm{B}$ produce inhibitors of NF- $\kappa \mathrm{B}$ actions $(\mathrm{I} \kappa \mathrm{B})$. In most quiescent normal cells, the NF- $\kappa \mathrm{B}$ dimers are squelched in the cytoplasm by associating with $\mathrm{I} \kappa \mathrm{B}$ proteins. There are 7 members of the $\mathrm{I} \kappa \mathrm{B}$ family that can potentially inhibit $\mathrm{NF}-\kappa \mathrm{B}$ function in the cytoplasm. $\mathrm{I} \kappa \mathrm{B}$ is a major molecular target for blocking $\mathrm{NF}-\kappa \mathrm{B}$ activation and 


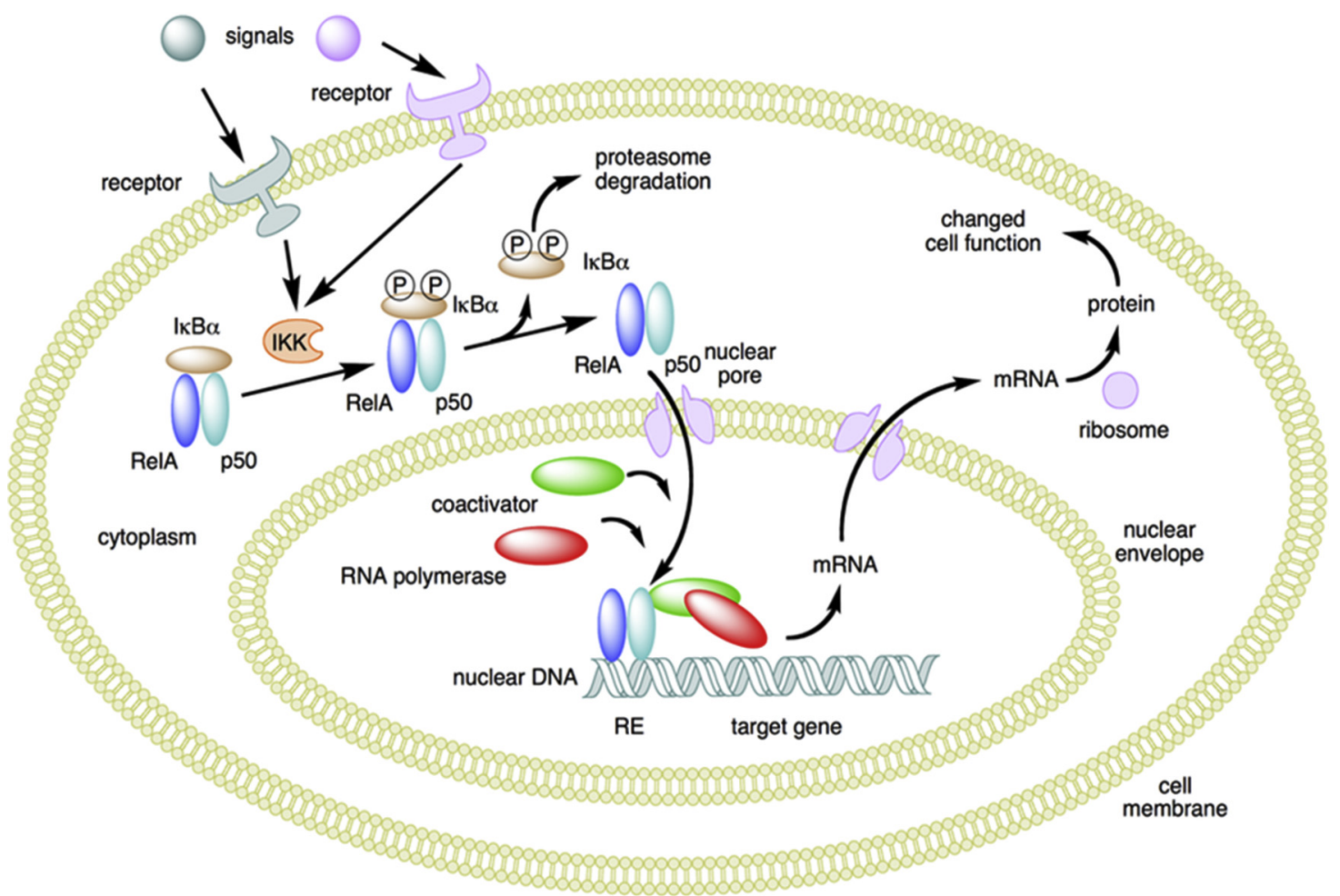

FIGURE 1. Mechanism of nuclear factor $\kappa \mathrm{B}$ action. In this figure, the nuclear factor $\kappa \mathrm{B}$ heterodimer (RelA and $p 50$ proteins) is used as an example. While in an inactivated state, nuclear factor $\kappa \mathrm{B}$ is located in the cytosol complexed with the inhibitory protein $(I \kappa B \alpha)$. A variety of extracellular signals can activate the enzyme $\mathrm{I} \kappa \mathrm{B}$ kinase $(I K K)$. I $\kappa \mathrm{B}$ kinase in turn phosphorylates the $\mathrm{I} \kappa \mathrm{B} \alpha$ protein (represented by $P$ in the diagram), which results in dissociation of $\mathrm{I} \kappa \mathrm{B} \alpha$ from nuclear factor $\kappa \mathrm{B}$ and eventual degradation of $\mathrm{I} \kappa \mathrm{B} \alpha$. The activated NF- $\kappa \mathrm{B}$ is then translocated into the nucleus, where it binds to specific sequences of DNA called response elements $(R E)$. The DNA/NF- $\kappa$ B complex then recruits other proteins, such as coactivators and RNA polymerase, which transcribe downstream DNA into messenger RNA ( $m R N A$ ), which in turn is translated into protein, which results in a change of cell function. (From https://commons, wikimedia.org/w/index.php?curid=3072083.)

subsequent gene transcription (eg, bortezomib is a reversible proteasome inhibitor of the degradation of $\mathrm{I} \kappa \mathrm{B}$ and is US Food and Drug Administration approved for cancer treatment, especially multiple myeloma, when used in conjunction with other cancer drugs ${ }^{4}$ ).

Inflammatory stimuli can trigger the degradation of $\mathrm{I} \kappa \mathrm{B}$ proteins through a kinase in the cytoplasm, causing the release of NF- $\kappa$ B followed by its translocation to the nucleus, where it modulates target gene transcription. Nuclear translocation of NF- $\kappa \mathrm{B}$ is a necessary component of gene activation by NF- $\kappa \mathrm{B}$. Xu and coauthors ${ }^{3}$ found that salu$\sin -\beta$ blockade inhibited monocrotaline-induced $\mathrm{I} \kappa \mathrm{B}$ degradation with subsequent decreased activation of NF- $\kappa \mathrm{B}$ in the lung tissue and intrapulmonary arterioles (see Figure 4 in the article of $\mathrm{Xu}$ and coauthors ${ }^{3}$ ). Further, they showed that salusin- $\beta$ blockade inhibited the nuclear translocation of NF- $\kappa \mathrm{B}$ in cultured human pulmonary endothelial cells (see Figure 6, $C$ and $D$, in the article of Xu and coauthors ${ }^{3}$ ).

The reason for describing the implications of NF- $\kappa \mathrm{B}$ regulation is to point out that they are complex. Tremendous progress has been made during the last 2 decades in unraveling the elaborate regulatory networks that control the
NF- $\kappa$ B response. This has made the NF- $\kappa$ B pathway a paradigm for understanding general principles of signal transduction and gene regulation. NF- $\kappa \mathrm{B}$ transcription factors are crucial players in an elaborate system that allows cells to respond to external stimuli, a process pivotal for survival and adaptation. A large number of diverse external stimuli lead to activation of NF- $\kappa \mathrm{B}$, and the genes whose expression is regulated by NF- $\kappa \mathrm{B}$ play important and conserved roles in immune and stress responses. ${ }^{5-8}$ It is extremely simplistic to ascribe $\mathrm{NF}-\kappa \mathrm{B}$ regulation to a single protein such as salusin- $\beta$. In their article, $\mathrm{Xu}$ and coauthors ${ }^{3}$ focus on salusin- $\beta$ to the exclusion of other potential mediators and other signaling pathways. I realize that they intended to perform a preliminary study of salusin- $\beta$; however, there is a very distinct possibility that other factors play an important role in NF- $\kappa \mathrm{B}$ activation-related $\mathrm{PAH}$, perhaps even to the exclusion of salusin- $\beta$. Further, $\mathrm{Xu}$ and coauthors ${ }^{3}$ point out in their Discussion section that the effects of salusin- $\beta$ on signaling in other inflammatory pathways are unknown.

The results described in the article by Xu and coauthors ${ }^{3}$ are intriguing, but further studies are needed to identify the 
impact of altering salusin- $\beta$-induced NF- $\kappa \mathrm{B}$ activation as a therapeutic target for the treatment or prevention of PAH. Identification of drugs that can target salusin- $\beta$ inhibition and that might have some use as therapeutic agents are important next steps. The work of $\mathrm{Xu}$ and coauthors ${ }^{3}$ is very preliminary but quite promising. Nonsteroidal antiinflammatory drugs, including sulindac, aspirin, ibuprofen, indomethacin, and cyclooxygenase- 2 inhibitors, are potential NF- $\kappa$ B blockers. They function either by suppressing the inflammatory cell response to indirectly suppress NF- $\kappa \mathrm{B}$ or by directly suppressing NF- $\kappa \mathrm{B}$ at key points along the NF- $\kappa$ B activation pathway. Whether any antiinflammatory agents have effects on salusin- $\beta$ function is uncertain, but investigation of this question surely must be an important next step. I look forward to future contributions from these authors regarding the impact of salusin- $\beta$ on nuclear transcription.

\section{References}

1. Shichiri M, Ishimaru S, Ota T, Nishikawa T, Isogai T, Hirata Y. Salusins: newly identified bioactive peptides with hemodynamic and mitogenic activities. Nat Med. 2003;9:1166-72.

2. Koya T, Miyazaki T, Watanabe T, Shichiri M, Atsumi T, Kim-Kaneyama JR, et al. Salusin- $\beta$ accelerates inflammatory responses in vascular endothelial cells via NF$\kappa \mathrm{B}$ signaling in LDL receptor-deficient mice in vivo and HUVECs in vitro. Am J Physiol Heart Circ Physiol. 2012;303:H96-105.

3. Xu T, Zhang Z, Liu T, Zhang W, Liu J, Wang W, et al. Salusin- $\beta$ contributes to vascular inflammation associated with pulmonary arterial hypertension in rats. J Thorac Cardiovase Surg. 2016;152:1177-87.

4. Hideshima T, Ikeda H, Chauhan D, Okawa Y, Raje N, Podar K, et al. Bortezomib induces canonical nuclear factor $-\kappa \mathrm{B}$ activation in multiple myeloma cells. Blood. 2009; 114:1046-52.

5. Oeckinghaus A, Ghosh S. The NF- $\kappa$ B family of transcription factors and its regulation. Cold Spring Harb Perspect Biol. 2009;1:a000034.

6. Berger T, Saunders ME, Mak TW. Dissection of signaling in inflammation: three novel inflammatory regulators. Cold Spring Harb Symp Quant Biol. 2013;78:141-7.

7. Niederberger E, Geisslinger G. Proteomics and NF-K: an update. Expert Rev Proteomics. 2013;10:189-204.

8. Mitchell S, Vargas J, Hoffmann A. Signaling via the $\mathrm{NF} \kappa \mathrm{B}$ system. Wiley Interdiscip Rev Syst Biol Med. 2016;8:227-41. 